\title{
Phytochemistry and medicinal values of Mahonia bealei: A review
}

\author{
Mohib Ullah Kakar ${ }^{1,2}$, Muhammad Saeed ${ }^{3}$, Ke Luo ${ }^{1}$, Imran Suheryani ${ }^{1}$, Wu \\ Shuang ${ }^{1}$, Yulin Deng ${ }^{1}$, Rongji Dai ${ }^{1 *}$ \\ ${ }^{1}$ School of Life Sciences and Technology, Beijing Institute of Technology, Beijing 100081, PR China, ${ }^{2}$ Faculty of Marine \\ Sciences, Lasbela University of Agriculture, Water and Marine Sciences, Uthal, Balochistan, ${ }^{3}$ Faculty of Animal Production \& \\ Technology, The Cholistan University of Veterinary and Animal Sciences, Bahawalpur, Pakistan
}

*For correspondence: Email: dairongji@bit.edu.cn; Tel: 0086-01068949331

Sent for review: 30 May 2019

Revised accepted: 25 September 2019

\begin{abstract}
Purpose: To review the medicinal uses of Mahonia bealei, an important member of the genus Mahonia, with a focus on its various applications in Traditional Chinese Medicine, as well as published scientific evidence on its effectiveness.

Methods: Information in all available literature was retrieved using different search engines including NCBI, ISI Web of Knowledge and Google.

Results: Several compounds have been extracted from $M$. bealei. These include alkaloids, triterpenes, flavonoids, phytosterols and lignans. Traditionally, the plant is used to treat dysentery, diarrhea and inflammation. Globally, scientists have used in vitro and in vivo techniques to evaluate the usefulness of compounds extracted from $M$. bealei with respect to their antibacterial, anti-inflammatory, antitumor, antioxidant as well as anti-gastrin properties.

Conclusion: Different parts of this plant still remain underexplored. Moreover, comparison of the properties of the isolated compounds has not been carried out, nor are there reports on the synergistic effects of extracts of the plant. Therefore, future research to address these areas may be useful in the discovery of new therapeutic agents.
\end{abstract}

Keywords: Berberidaceae, Mahonia bealei, Traditional Chinese Medicine, Alkaloids, Flavonoids, Antiinflammatory activity, Anti-tumor activity

\begin{abstract}
This is an Open Access article that uses a fund-ing model which does not charge readers or their institutions for access and distributed under the terms of the Creative Commons Attribution License (http://creativecommons.org/licenses/by/4.0) and the Budapest Open Access Initiative (http://www.budapestopenaccessinitiative.org/read), which permit unrestricted use, distribution, and reproduction in any medium, provided the original work is properly credited.

Tropical Journal of Pharmaceutical Research is indexed by Science Citation Index (SciSearch), Scopus, International Pharmaceutical Abstract, Chemical Abstracts, Embase, Index Copernicus, EBSCO, African Index Medicus, JournalSeek, Journal Citation Reports/Science Edition, Directory of Open Access Journals (DOAJ), African Journal Online, Bioline International, Open-J-Gate and Pharmacy Abstracts
\end{abstract}

\section{INTRODUCTION}

Mahonia bealei belongs to the family Berberidaceae and genus Mahonia. Geographically, this evergreen shrub is widely distributed in America, Europe and Asia [1]. Mahonia is a genus containing more than 60 species, and more than 30 species of this genus grow in the southwest area of China [2]. The genus Mahonia is a member of basal eudicots which consists of coriaceous (sclerophyllous) evergreen small trees or shrubs with compound leaves $[2,4]$. It has been revealed that 20 species of this genus are distributed in southwestern parts of the United States of America [4]. Some of the species are also present in Europe as 
invasive plants [5].

Traditional Chinese Medicine (TCM) has a long history of usage of materials derived from botanical, animal as well as mineral resources. These agents have been classified according to their sources, color, habitats, way of collection, parts of the plant collected and the methods of prescription, by $\mathrm{Li}$ in his famous work Ben Cao Kong Mu (The Classical TCM Pharmacopeia) [6]. In TCM, the roots, stem and leaves of Mahonia have been used for the treatment of different diseases such as diarrhea and dysentery for centuries. These plants are recognized by the Chinese Pharmacopeia Commission for their moisturizing effects, heat-clearing properties, and as detoxifying agents [7].

Another important species with similar properties reported in TCM is bai-yang-jie (Arundina graminifolia) [8]. In TCM, Mahonia Caulis which comprises dried stem of Mahonia bealei (Fort.) Carr. and $M$. fortune (Lindl.) Fedde is an important medicine. It has been used for long for treating icteric hepatitis, conjunctivitis, ulcers, boils, carbuncles, toothache, and ailments that were thought to be due to fire of stomach [9]. The leaves of Mahonia bealei have been used to produce bitter tea, and are rich in polyphenolic compounds with potent antioxidant properties [10]. There have been numerous reports showing the antioxidant potential of the leaves when consumed in the form of tea like black tea which is used worldwide [11].

Studies have shown that the chemical composition of different compounds from Mahonia bealei is important for their use in pharmaceutical industry $[1,12,13]$. The leaves of Mahonia bealei are an important source of beneficial natural compounds that need to be explored [14]. Phytochemical studies have revealed that the stem and roots of $M$. bealei are rich in cerebrosides and alkaloids [15]. Different parts of the genus Mahonia, such as stem, bark, leaves and fruits of have been extensively used, and possess a long history of application in TCM [16-20]. Phytochemical studies on Mahonia species have been very beneficial in the isolation of sterols, alkaloids, flavonoids and glycosides [1].

The present study summarized the number of useful compounds isolated from Mahonia bealei and their structures. In addition, the medicinal uses of these compounds were reviewed, and a comparison of the medicinal uses of the plant in $\mathrm{TCM}$, in relation to experimental findings was made. Future prospects regarding studies of this species were also proposed in this review.

\section{Morphology and distribution of Mahonia bealei}

Mahonia bealei (also called leatherleaf Mahonia) is an evergreen shrub that grows to a height of about 5 to 10 feet $(1.5$ to $3 \mathrm{~m})$. Pinnately compound leaves are present which are 18 inches $(46 \mathrm{~cm})$ long and contain $9-13$ holly-like leaflets 1 to 2 inches $(2.5$ to $5.1 \mathrm{~cm}$ ) wide, and 2 to 4 inches $(5$ to $10 \mathrm{~cm}$ ) long. The time of flowering of this plant is from late winter to early spring. The flowering starts with the development of fragrant, lemon-yellow flowers. The fruits are green berries which later turn to blue black color and increase in size to half an inch, while hanging from the plant. Although the plant is native to China, it is an invasive plant in parts the United States of America, especially the southern region, and it has been categorized as an ornamental shrub [21]. Figure 1 shows the different parts of this plant.

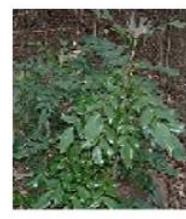

(a)

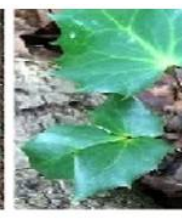

(b)

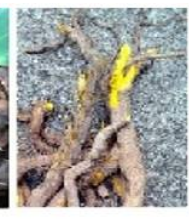

(c)

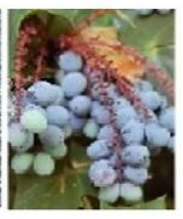

(d)
Figure 1: Mahonia bealei. (a): The arial parts of Mahonia bealei growing among other plants; (b): leaves of $M$. bealei; (c): roots of Mahonia bealei; (d): fruits of Mahonia bealei

\section{Compounds isolated from Mahonia bealei}

The extraction of compounds from medicinally important plants and investigations of their medicinal uses are important areas of scientific research. Different parts of Mahonia bealei have been studied. In this section, the number, nature and structure of compounds isolated from this species to date, are summarized.

\section{Alkaloids}

Studies have shown that isoquinoline alkaloids constitute a major subclass of alkaloids isolated from the genus Mahonia. These compounds are responsible for many properties exhibited by plants of this genus. A study has shown that the roots, stem and leaves of $M$. bealei contain the three alkaloids berberine, palmatine, and jatrorrhizine [22]. The major alkaloid found in leaves was berberine, while the roots and stem contained jatrorrhizine and berberine [23]. The structures of these alkaloids are given in Figure 2 and Figure 3 [30]. 


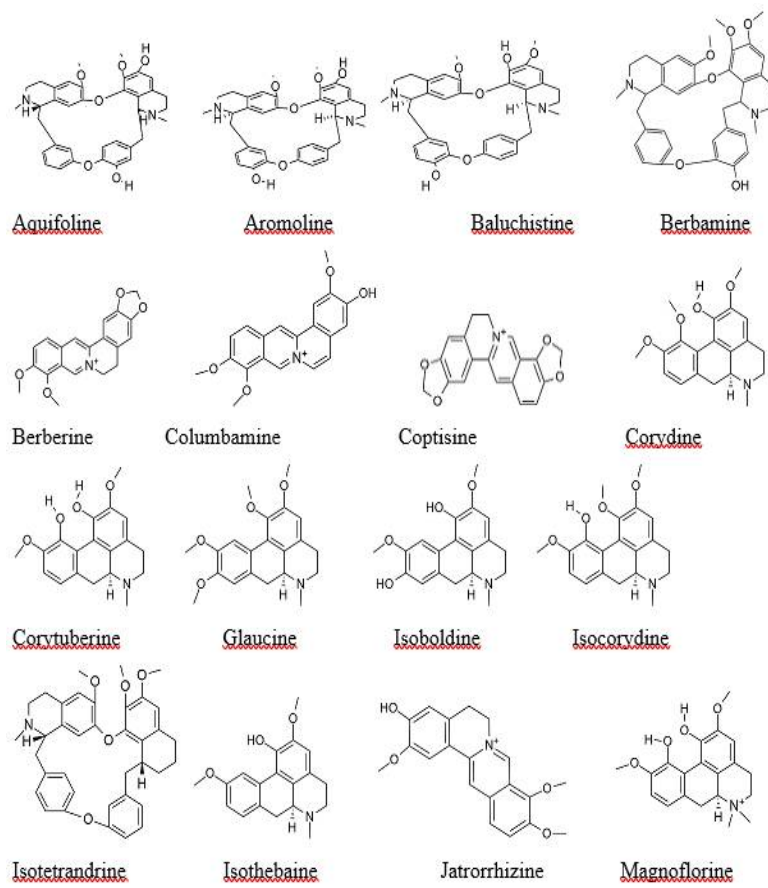

Figure 2: Structures of alkaloids isolated from Mahonia bealei

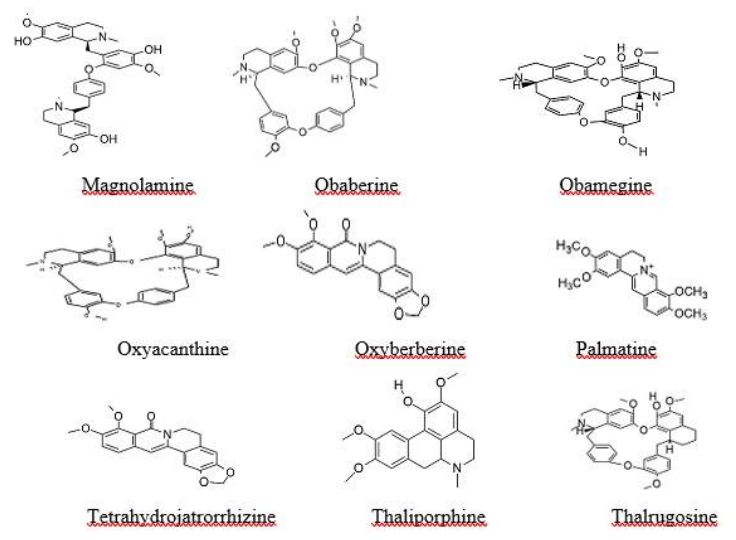

Figure 3: Structures of alkaloids isolated from Mahonia bealei

\section{Triterpenes}

To the best of our knowledge, so far, only three triterpenes have been isolated from the leaves of M. bealei. These compounds, identified as ursolic acid, oleanolic acid and oleanolic acid 3$O-\beta$-D-glucopyranoside, were for the first time isolated from the species of the genus Mahonia [15]. Later-on, 3-O- $\beta$-D-glucopyranoside was isolated from the branches of this plant [24]. The structures of these triterpenes are given in Figure 4.

\section{Flavonoids}

Certain flavonoids have been isolated from the leaves and branches of $M$. bealei. These flavonoids are quercetin and quercetin 3- $O-\beta-D-$ xylopyranoside [25]. Later studies also reported the isolation of tamarixetin 3-O- $\beta-D-$ glucopyranoside, quercetin 3-O- $\beta$-Dxylopyranoside, isorhamnetin 3-O- $\alpha$-Lrhamnopyranoside, luteolin, isorhamnetin, tricin, and chryseriol. The structures of these flavonoids are shown in Figure 5.

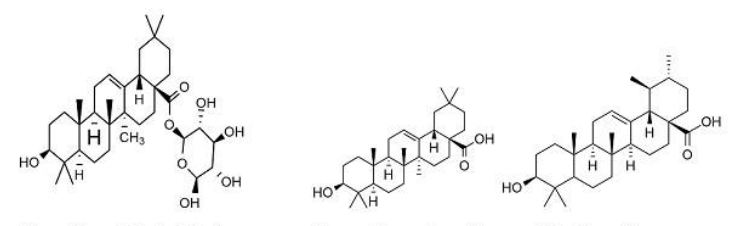

Oleanolic acid 3-O- $\beta$-D-glucopyranoside Oleanolic acid Ursolic acid

Figure 4: Structures of triterpenes isolated from M. bealei

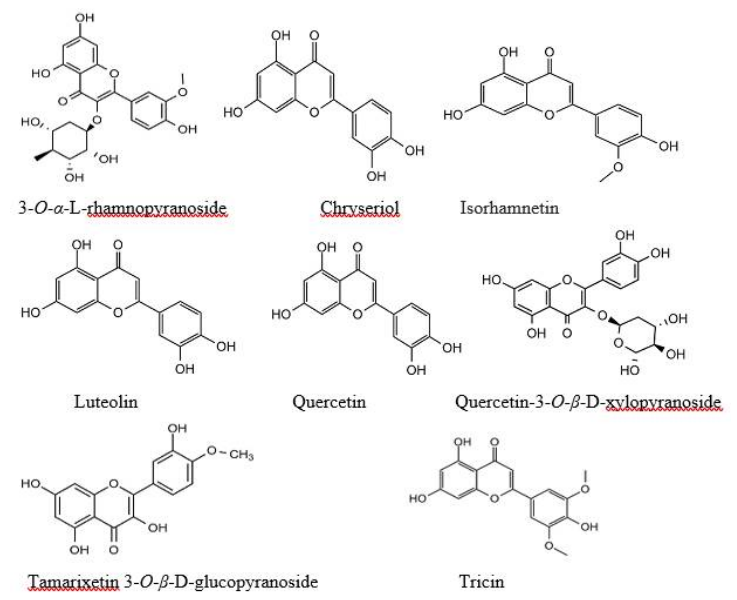

Figure 5: Flavonoids from M. bealei

\section{Phytosterols}

Two phytosterols have been isolated from Mahonia bealei. A stigmasterol was reported after NMR and MS spectroscopic studies of methanol extract of the plant [25]. In another study, $70 \%$ ethanol extract of the stem of Mahonia bealei yielded $\beta$-sitosterol [26]. The structures of these phytosterols are shown in Figure 6.
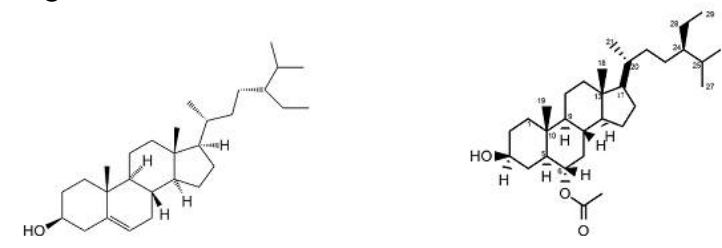

$\beta$-Sitosterol

Stigmastero

Figure 6: Phytosterols isolated from M. bealei

\section{Lignans}

Four lignans have been isolated from Mahonia bealei. A study of $70 \%$ ethanol extract of the

Trop J Pharm Res, October 2019; 18(10):2221 
stem of Mahonia bealei using chromatographic separation techniques yielded episyringaresinol which was characterized by mass spectrometry [26]. Later on, another study conducted on the ethyl acetate fraction of the trunk of $M$. bealei yielded three more lignans identified as yangambin, epiyangambin and bishexadecyl epiphyllate [25]. The structures of these lignans are given in Figure 7.

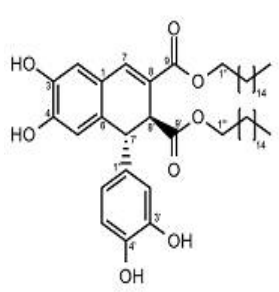

Bishexadecyl eppiphyllate

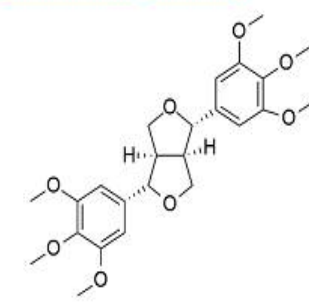

Epivangambin

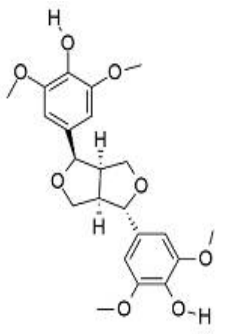

Episyringaresinol

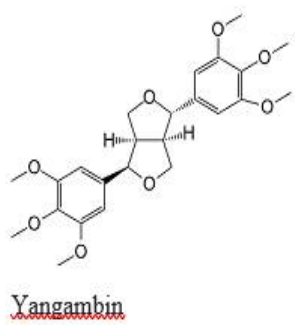

Yangambin
Figure 7: Lignans isolated from $M$. bealei

\section{Other compounds isolated from M. bealei}

In addition to the classes of compounds already presented, several compounds from other classes have been isolated, although in less abundant amounts, from different parts of $M$. bealei. Erythro-syringoyl glycerol $8-O-\beta-D$ glucoside; $3,4,5$-trimethoxyphenyl-1-O- $\beta-D$ glucoside, and 5,5-dimethoxylariciresinol- 4-O$\beta$ - $D$-glucoside were identified from the stem extracts of $M$. bealei [26]. Another study isolated three compounds belonging to phenolic, steroidal and phenylpropanoid groups. These were identified as methyl syringate, daucosterol, and 3-(4-hydroxy-3, 5- dimethoxyphenyl)-3-ethoxy-2sulfopropane-1-ol, respectively. Later on, gallic acid and trans-cinnamic acid were identified from extracts of the branches of Mahonia bealei after isolation, purification and characterization [24]. The structures of these compounds are given in Figure 8.

\section{MEDICINAL USES OF COMPOUNDS ISOLATED FROM M. BEALEI}

Several medicinal uses of the compounds extracted from $M$. bealei have been reported. These are reviewed below.
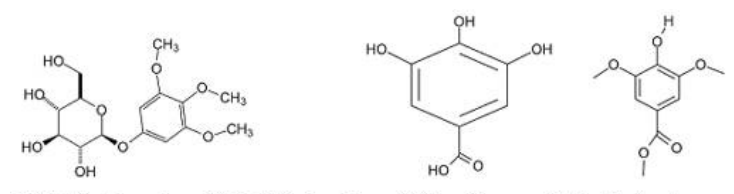

3,4,5-trimethoxyphenyl-1-O- $\beta$ - $D$-glucoside Gallic acid Methy1 Syringate
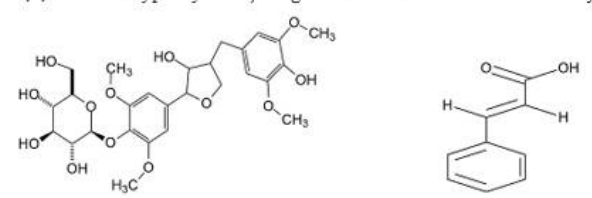

5,5-dimethoxvlariciresinol- 4-O- $\beta$-D-glucoside Ttans-Cinnamic acid

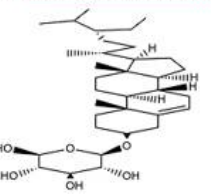

Oे
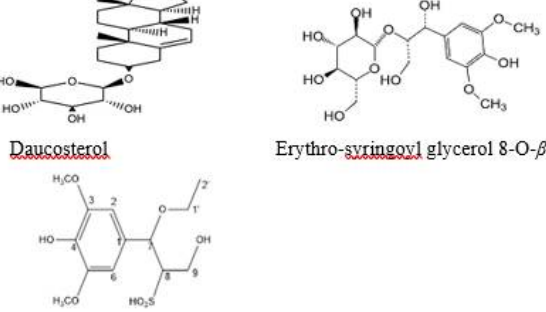

Erythro-syringovl glycerol 8-O- $\beta$ - $D$-glucoside

3-(4-hydroxy-3, 5- dimethoxyphenyl)-3-ethoxy-2-sulfopropane-1-o1

Figure 8: Other groups of compounds isolated from M. bealei

\section{Antimicrobial properties}

In TCM, the plants from genus Mahonia are known to inhibit bacteria. Mahonia caulis consists of $M$. bealei (Fort). Carr and M. fortune (Lindl.) Fedde. These plants were used as antipneumoconiosis, anti-nociceptive, as well as antipyretic agents [27,28]. Studies have shown that ethanol extracts of stems and leaves of $M$. bealei are effective against Staphylococcus aureus, Bacillus thuringiensis and Bacillus subtilis, but not effective against gram positive bacteria. The stem extract of $M$. bealei was more effective than the leaf extract. The most effective antimicrobial activity exhibited by the stem extract was against Staphylococcus aureus, with minimum inhibitory concentration (MIC) of 0.58 $\mathrm{mg} / \mathrm{ml}$, relative to the leaf extract with MIC of $2.30 \mathrm{mg} / \mathrm{ml}[18]$.

Another study showed that extracts of Mahonia bealei, whether tanninized or de-tanninized, did not show any activity against clinically important multidrug resistant pathogenic strains of Acinetobacter baumannii 31P, 125 and 152P [29]. However, a US patent document showed a preparation method for the extract of Mahonia bealei that exerted biostatic effects on Escherichia coli, Staphylococcus aureus and Enterococcus faecalis. Inhibitory effect was not reported on Klebsiella pneumonia, Pseudomonas aeruginosa and Enterobacter cloacae. An important feature of this invention is the simple method of extract preparation using the stem and 
leaves of Mahonia bealei as raw materials, with water, ethanol or water-containing alcohol as solvent. This patent emphasizes the antibacterial activity of $M$. bealei[30]. It has been reported that alkaloid extract of the roots of $M$. bealei (Fort.) Carr. inhibited the proliferation of Avian influenza virus (Al) in embryos at a dose of $0.25 \mathrm{mg} / \mathrm{ml}$, and showed no adverse side effects on the experimental embryos, even at doses up to 20 $\mathrm{mg} / \mathrm{ml}[31]$.

\section{Antitumor properties}

A study has reported that water extract of leaves of $M$. bealei inhibited the proliferation of human colon cancer (HT-29) cells [10]. Molecular and chromatographic evidence indicated that the proportion of apoptotic cells increased while the expression of survivin gene was downregulated [10]. The survivin gene is an important member of an apoptotic family of inhibitors which presence results in the prevention of apoptotic cell death while it promotes proliferation of cells. Studies have revealed that survivin gene expression is upregulated in tumors, while its expression is normally downregulated in normal cells [32]. After evaluation of antitumor property in [10], the compound responsible for the antitumor effect was identified through sequential partitioning of the aqueous extract of $M$. bealei leaves using ethyl acetate, $n$-butanol and dichloromethane. Cytotoxicity of each fraction was assessed against HT-29 cells and it was revealed that the dichloromethane fraction was active against HT-29 cell lines. Further studies showed that the anticancer effect was due to the presence of berberine, which had $\mathrm{IC}_{50}$ of 36.54 $\mu \mathrm{M}$ for HT-29 cells [10]. In another investigation, palmatine, an alkaloid obtained from $M$. bealei was shown to exhibit anti-proliferative properties as well as cytokine-lowering effects in vitro and in vivo [33]. Previous research had shown that an important risk factor for tumor development (including colorectal cancer) was chronic inflammation, while inhibition of inflammatory pathway was effective in preventing the development of colon cancer [34, 35]. In vitro studies to check levels of production of LPSinduced inflammatory cytokines showed higher cytokine levels in HT-29 cell lines than in SW480 cell lines, while the administration of palmatine resulted in significant reduction of IL8 cytokine levels in HT-29 cell lines. Results of in vivo studies showed that oral administration of palmatine at doses of 10 or $20 \mathrm{mg} / \mathrm{kg} /$ day in $\mathrm{APC}^{\mathrm{min} /+}$ resulted in significant reduction of tumor numbers in colon and small intestine. Therefore, orally-administered palmatine may have significant therapeutic potential for colorectal cancer [33]. Since palmatine obtained from
Mahonia bealei and orally administered $M$. bealei were used in the above study, it was concluded that $M$. bealei possesses antitumor properties [33].

\section{Antioxidant effects}

Studies have shown that free radicals are major causes of oxidative damage to biological molecules as a result of which diseases like cancer, coronary heart disease and dementia develop. Free radicals are also considered major factors in the aging process [35]. A study of the water extract of leaves of Mahonia bealei (Fort) Carr. showed that it exhibited antioxidant properties. The stable free radical 2, 2-diphenyl1-picrylhydrazyl (DPPH) is used for the evaluation of reducing substances in biological systems as well as foods [36]. Experimental evidence revealed that leaf extract of Mahonia bealei exhibited DPPH free radical scavenging effect in concentration-dependent manner, with a concentration of $100 \mu \mathrm{g} / \mathrm{ml}$ producing the highest $(73.67 \%)$ scavenging effect [10]. The superoxide radical brings about oxidative damage to cells [37]. The aqueous leaf extract of $M$. bealei scavenged superoxide anions in a concentrationdependent manner, and significantly reduced oxidative modification of proteins [10]. Proteins are one of the major targets of oxidative damage by free radicals [38]. In another study, it was shown that ethanol extract of $M$. bealei exhibited anti-radical effects against DPPH, with $\mathrm{IC}_{50}$ value of $80.0 \mu \mathrm{g} / \mathrm{ml}$, and against $A B T S^{+}$with $I_{50}$ value of $26.2 \mu \mathrm{g} / \mathrm{ml}$ [39].

\section{Anti-gastrin effect}

Gastric ulcer is an important and common pathological condition that causes loss of weight, loss of appetite, vomiting, heartburn and other clinical manifestations [40]. In the clinical treatment of gastric ulcer, the inhibition of gastric acid secretion is very important because gastric acid has been identified as the key pathogenic factor of the disease [41]. Historically, the introduction of $\mathrm{H}_{2}$ receptor antagonists and proton pump inhibitors that target gastric $\mathrm{H}^{+} / \mathrm{K}^{+}$ATPase resulted in a major breakthrough with respect to the treatment of gastroesophageal reflux diseases and peptic ulcer $[42,43]$. Studies show that gastric $\mathrm{H}^{+} / \mathrm{K}^{+}$-ATPase is responsible for the acidification of stomach. It is a proton pump which stimulates gastric acid production. The inhibition of this pump is useful in clinical treatment of reflux disease, peptic ulcer and dyspepsia [42].

Previous studies showed that other medicinal plants in TCM such as Dregea sinensis Hemsl. 
(Daibaiji) and Dracaena cochinchinensis (Lour.) (also called dragon's blood) exerted gastroprotective effects in vivo [44,45]. A study has shown that total alkaloids from the stem of $M$. bealei, when applied on experimental rats lowered the content of gastrin by inhibiting $\mathrm{H}^{+} / \mathrm{K}^{+}$ATPase activity, resulting in reduction of gastric acidity. A $57 \%$ protective effect of total alkaloids from $M$. bealei was observed on pyloric ligationinduced gastric ulcer in rats in vivo, relative to 63 $\%$ protection by the positive control omeprazole [13].

\section{Anti-inflammatory effects}

Inflammation is an important response that is ubiquitously produced as a defense mechanism against pathogens in all organisms. Macrophages are major immune cells that play a key role in the onset of inflammation [46]. The results obtained from in in vivo and in vitro experiments have indicated that the leaves of $M$. bealei (Fort.) Carr. possess anti-inflammatory properties [47]. A key factor in initiating inflammatory response is the production of NO free radical which acts as a major factor that triggers inflammatory responses [48]. Along with in vitro study on cell lines, an in vivo study was also conducted using lipopolysaccharide-induced acute lung injury (ALI) in the mouse model. This model was used because inflammatory response is triggered in lung injury, and TNF- $\alpha$ and IL-6 are important indicators of early onset of inflammatory response [49].

Using mouse model, it has been revealed that the levels of inflammatory mediators are reduced by treatment with the dichloromethane fraction of leaves of Mahonia bealei (Fort). Carr. [47]. A study showed that a triterpene obtained from the leaves of Mahonia bealei reduced the production of cytokines, downregulated MAPK pathway, and inhibited activation of NF-kB [50].

A summary and comparison of traditional medicinal uses of different parts of $M$. bealei, and scientific evidence reported based on research conducted by different scientists are shown in Table 1.

A summary of classes of useful compounds obtained from different parts of Mahonia bealei, their traditional medicinal uses, and scientific evidence obtained to date are presented in Figure 9.

\section{CONCLUDING REMARKS}

Mahonia bealei has been traditionally used for medicinal purposes throughout the ancient times. With the advancement of scientific research, scientific evidence is being explored to establish the bases for the uses of the plant. Although several compounds from the roots, stem and leaves of Mahonia bealei have been extracted and used in different studies, a lot still needs to be done. A comparison of traditional uses of different parts of Mahonia bealei with scientific evidence reported to date shows that many uses of the have not yet been scientifically investigated. Therefore, future research require more studies on different parts of this plant. A comparison of the properties of different solvent extracts of different parts of the plant is also required. More importantly, studies of possible synergistic effects of different extracts may lead to discovery of new therapeutic uses of this plant.

Table 1: Summary of traditional uses of Mahonia bealei and reported activities

\begin{tabular}{|c|c|c|c|c|c|c|}
\hline S/no. & $\begin{array}{l}\text { Part of plant } \\
\text { used }\end{array}$ & Traditional uses & Reference & Scientific study & Source & Reference \\
\hline 1 & $\begin{array}{l}\text { Roots, stem and } \\
\text { leaves }\end{array}$ & Diarrhea & Pharmacopeia [7] & No Reported & - & - \\
\hline 2 & $\begin{array}{l}\text { Roots, stem and } \\
\text { leaves }\end{array}$ & Dysentery & Pharmacopeia [7] & Not Reported & - & - \\
\hline 3 & $\begin{array}{l}\text { Roots, stem and } \\
\text { leaves }\end{array}$ & Clearing heat & Pharmacopeia [7] & $\begin{array}{l}\text { Antiinflammatory } \\
\text { Activity }\end{array}$ & Leaves & {$[47,49]$} \\
\hline 4 & Leaves and fruit & Detoxification & $\begin{array}{l}\text { Chinese } \\
\text { Pharmacopoeia } \\
\text { [9] }\end{array}$ & $\begin{array}{l}\text { Antioxidant } \\
\text { Activity }\end{array}$ & Leaves & {$[10,39]$} \\
\hline 5 & Dried stem & $\begin{array}{l}\text { Icteric hepatitis } \\
\text { conjunctivitis }\end{array}$ & Pharmacopeia [7] & Not Reported & - & - \\
\hline 6 & Dried stem & Ulcers & Pharmacopeia [7] & $\begin{array}{l}\text { Anti-gastrin } \\
\text { Activity }\end{array}$ & Stem & [13] \\
\hline 7 & Dried stem & Carbuncles & Pharmacopeia [7] & Not Reported & - & - \\
\hline 8 & Dried stem & Toothache & Pharmacopeia [7] & Not Reported & - & - \\
\hline 9 & Dried stem & Stomach fire & Pharmacopeia [7] & $\begin{array}{l}\text { Anti-gastrin } \\
\text { Activity }\end{array}$ & Stem & [13] \\
\hline
\end{tabular}




\begin{tabular}{|c|c|c|c|c|c|}
\hline 10 & Roots & Antipyretic & {$[27,28]$} & $\begin{array}{l}\text { Antimicrobial } \\
\text { Activity }\end{array}$ & $\begin{array}{l}\text { Stem and }[18,29-31] \\
\text { Leaves }\end{array}$ \\
\hline
\end{tabular}

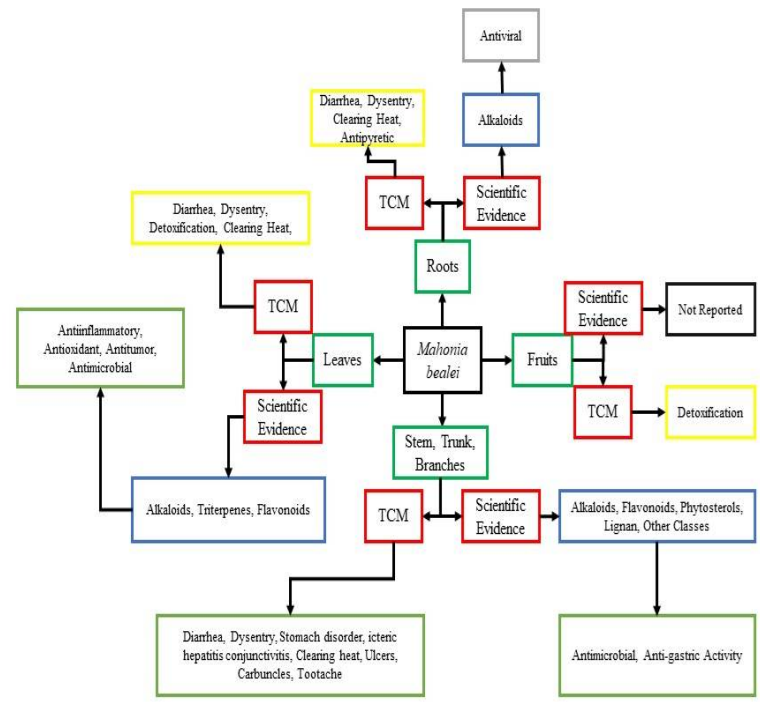

Figure 9: A scheme showing classes of useful compounds obtained from different parts of Mahonia bealei, their traditional medicinal uses, and scientific evidence obtained to date

\section{DECLARATIONS}

\section{Conflict of interest}

No conflict of interest is associated with this work.

\section{Contribution of authors}

We declare that this work was done by the authors named in this article, and all liabilities pertaining to claims relating to the content of this article will be borne by the authors. Mohibullah Kakar generated the idea, searched and compiled the data. Muhammad Saeed and Ke Lou helped in the compilation and searching of data. Imran Suheryani and Wu Shuang helped in the arrangement and writing of the review. Yulin Deng and Rongji Dai provided all the funding and guidelines for the manuscript.

\section{Open Access}

This is an Open Access article that uses a funding model which does not charge readers or their institutions for access and distributed under the terms of the Creative Commons Attribution License (http://creativecommons.org/licenses/by/ 4.0) and the Budapest Open Access Initiative (http://www.budapestopenaccessinitiative.org/rea d), which permit unrestricted use, distribution, and reproduction in any medium, provided the original work is properly credited.

\section{REFERENCES}

1. He JM, Mu Q. The medicinal uses of the genus Mahonia in traditional Chinese medicine: An ethnopharmacological, phytochemical and pharmacological review. J Ethnopharmacol 2015; 175: 668-683.

2. China EC. Flora of China. Science Press Beijing.1998.

3. Ahrendt LWA. Berberis and mahonia: a taxonomic revision. Bot J Linn Soc 1961; 57: 1-410.

4. Loconte $H$. Berberidaceae. Flowering plants. dicotyledons: Springer; 1993; 147-152.

5. Auge $H$, Brandl $R$. Seedling recruitment in the invasive clonal shrub, Mahonia aquifolium Pursh (Nutt.). OECOLOGIA 1997; 110: 205-211.

6. Unschuld P. Medicine in China: history of pharmaceutics. University of California Press. Berkeley, CA. 1986.

7. Pharmacopeia C. China Medical Science Press. Beijing, China. 2010.

8. Liu $Q$, Wang $H$, Lin F, Dai R, lin Yu D, Lv F. Study on the structures and anti-hepatic fibrosis activity of stilbenoids from Arundina graminifolia (D. Don) Hochr. IOP Conf Ser Mater Sci Eng 2017; 274: 012024.

9. Commission CP. Chinese Pharmacopoeia (vol. 1). Chinese Medical Science and Technology Press, Beijing, China. 2010.

10. Hu W, Yu L, Wang MH. Antioxidant and antiproliferative properties of water extract from Mahonia bealei (Fort.) Carr. leaves. Food Chem Toxicol 2011; 49: 799-806.

11. Naveed M, Bibi J, Kamboh AA, Suheryani I, Kakar I, Fazlani SA, Fang XF, Kalhoro SA, Yumjuan L, Kakar $M U$, et al. Pharmacological values and therapeutic properties of black tea (Camellia sinensis): A comprehensive overview. Biomed Pharmacother 2018; 100: 521-531.

12. Zeng $X$, Dong $Y$, Sheng $G$, Dong $X$, Sun $X$, Fu J. Isolation and structure determination of anti-influenza component from Mahonia bealei. J Ethnopharmacol 2006; 108: 317-319.

13. Zhang SL, Li H, He X, Zhang RQ,. Sun $Y H$, Zhang $C F$, Wang CZ, Yuan CS. Alkaloids from Mahonia bealei posses anti-H(+)/K(+)-ATPase and anti-gastrin effects on pyloric ligation-induced gastric ulcer in rats. Phytomedicine 2014; 21: 1356-1363.

14. Wu L, Wang G, Shen T, You L, Hu W, Si CL. Optimizing conditions for antioxidant phenolic compound extraction from Mahonia bealei (Fort.) Carr. leaves using a response surface methodology. Hortic Environ Biotechnol 2017; 58: 282-91.

15. Wu L, Wang G, Shen T, Qiang Q, Xue Q, Chen M, Zhang J, Luo $Y$, Hong YM, Si CL, et al. Chemical constituents of leaves of Mahonia bealei. Chem Nat Comp 2018; 54 : 210-212.

16. Chao J, Lu TC, Liao JW, Huang TH, Lee MS, Cheng HY, Ho LK, Kuo CL, Peng WH. Analgesic and anti-

Trop J Pharm Res, October 2019; 18(10):2225 
inflammatory activities of ethanol root extract of Mahonia oiwakensis in mice. J Ethnopharmacol 2009; 125: 297 303.

17. Li A, Zhu $Y$, He $X$, Tian $X, X u L$, Ni $W$, Jiang $P$. Evaluation of antimicrobial activity of certain Chinese plants used in folkloric medicine. World J Microbiol Biotechnol 2008; 24: 569-572.

18. Li AR, Zhu Y, Li XN, Tian XJ. Antimicrobial activity of four species of Berberidaceae. Fitoterapia 2007; 78: 379381.

19. Li Y, Ji X, Liu H, Yan Y, Li J. Characterization of 10 species of Mahonia by capillary electrophoresis. Chromatographia 2000; 51: 357-361.

20. Rackova L, Oblozinsky M, Kostalova D, Kettmann V, Bezakova $L$. Free radical scavenging activity and lipoxygenase inhibition of Mahonia aquifolium extract and isoquinoline alkaloids. J Inflamm (Lond) 2007; 4: 15.

21. eXtension.org. A part of the cooperative extension system: 2019. Available on: https://articles.extension.org/pages/62638/mahoniabealei-leatherleaf-mahonia, retrieved 10 March 2019.

22. Ji X, Li Y, LiU H, Yan Y, Li J. Determination of the alkaloid content in different parts of some Mahonia plants by HPCE. Pharm Acta Helv 2000; 74: 387-391.

23. Zhang L, Zhu W, Zhang Y, Yang B, Fu Z, Li X, Tian J. Proteomics analysis of Mahonia bealei leaves with induction of alkaloids via combinatorial peptide ligand libraries. J Proteomics 2014; 110: 59-71.

24. Wu L, Shen T, Zhou Y, Wu J, Ji XY, Si CL, Hu WC. Secondary metabolites of Mahonia bealei branches. Chem Nat Comp 2018; 54: 564-566.

25. Thanh BV, Anh NTV, Giang DH, Dang NH, Anh LDN, Huong BV, Phuong ND, Dat NT. Non-alkaloid constituents from Mahonia bealei. Nat Prod Commun 2017; 12: 1619-1621.

26. Cong Y, Wang Y, Wang T, Li Q. Chemical constituents from the stem of Mahonia bealei (Fort.) Carr. Chin Tradit Pat Med 2011; 33: 1008-1010.

27. Küpeli E, Koşar M, Yeşilada E, Başer KHC. A comparative study on the anti-inflammatory, antinociceptive and antipyretic effects of isoquinoline alkaloids from the roots of Turkish Berberis species. Life Sci 2002; 72: 645-657.

28. Yesilada E, Kupeli E. Berberis crataegina DC. root exhibits potent anti-inflammatory, analgesic and febrifuge effects in mice and rats. J Ethnopharmacol 2002; 79: 237-248.

29. Miyasaki Y, Rabenstein JD, Rhea J, Crouch ML, Mocek UM, Kittell PE, Morgan MA, Nichols WS, Benschotan MMV, Hardy WD, et al. Isolation and characterization of antimicrobial compounds in plant extracts against multidrug-resistant Acinetobacter baumannii. PloS One 2013; 8: e61594.

30. Lin Y, Wang Z, Honglin S, Wang N. Mahonia bealei extract with antibacterial inflammation-diminishing and granulation-promoting functions as well as preparation method and application thereof. Google Patents 2018; US20180099018A1.
31. Zeng X, Lao B, Dong X, Sun X, Dong Y, Sheng G, Fu G. Study on anti-influenza effect of alkaloids from roots of Mahnia bealei in vitro. Zhong Yao Cai 2003; 26: 29-30.

32. Ryan BM, O'Donovan N, Duffy MJ. Survivin: a new target for anti-cancer therapy. Cancer Treat Rev 2009; 35: 553-562.

33. Ma WK, Li H, Dong CL, He X, Guo CR, Zhang CF, Yu $\mathrm{CH}$, Wang CZ, Yuan CS. Palmatine from Mahonia bealei attenuates gut tumorigenesis in ApcMin/+ mice via inhibition of inflammatory cytokines. Mol Med Rep 2016; 14: 491-498.

34. Madka V, Rao CV. Anti-inflammatory phytochemicals for chemoprevention of colon cancer. Curr Cancer Drug Targets 2013; 13: 542-557.

35. Siriwardhana N, Lee KW, Jeon YJ, Kim SH, Haw JW. Antioxidant activity of Hizikia fusiformis on reactive oxygen species scavenging and lipid peroxidation inhibition. Food Sci Technol Int 2003; 9: 339-346.

36. Leong L, Shui G. An investigation of antioxidant capacity of fruits in Singapore markets. Food Chem 2002; 76: 6975.

37. Ak T, Gülçin I. Antioxidant and radical scavenging properties of curcumin. Chem Biol Interact 2008; 174: 27-37.

38. Hawkins CL, Morgan PE, Davies MJ. Quantification of protein modification by oxidants. Free Radic Biol Med 2009; 46: 965-988.

39. Zhang Y, Zou B, Yi Lin F, Yi X, Pan Y. Antioxidant activity of extract from Mahonia bealei Fruit. Journal of Guangxi Normal University (Natural Science Edition) 2011; 29: 43-46.

40. Lakshmi V, Singh N, Shrivastva S, Mishra S, Dharmani $P$, Mishra V, Palit G. Gedunin and photogedunin of Xylocarpus granatum show significant anti-secretory effects and protect the gastric mucosa of peptic ulcer in rats. Phytomedicine 2010; 17: 569-574.

41. Zhang Q, Huang N, Wang J, Luo H, He H, Ding M, Deng $W Q$, Zuo $K$. The $H_{+} / K_{+}-A T P a s e$ inhibitory activities of Trametenolic acid $B$ from Trametes lactinea (Berk.) Pat, and its effects on gastric cancer cells. Fitoterapia 2013; 89: 210-217.

42. Black J, Duncan W, Durant CJ, Ganellin CR, Parsons E. Definition and antagonism of histamine H2-receptors. Nature 1972; 236: 385-390.

43. Fellenius E, Berglindh T, Sachs G, Olbe L, Elander B, Sjöstrand SE, Wallmark B. Substituted benzimidazoles inhibit gastric acid secretion by blocking $\left(\mathrm{H}_{++} \mathrm{K+}\right)$ ATPase. Nature 1981; 290: 159.

44. Suheryani I, Li Y, Dai R, Liu X, Anwer S, Juan S, Deng Y. Gastroprotective effects of Dregea sinensis Hemsl.(Daibaijie) against aspirin-induced gastric ulcers in rats. Int J Pharmacol 2017; 13: 1047-1054.

45. Suheryani I, Yujuan L, Chen B, Panpan L, Xiujie L, Ansari $I A$, Saeed $O$, Rongji D, Yulin D. Gastroprotective effects of Dracaena cochinchinensis (Lour.) against aspirininduced gastric ulcers in rats. Int J Pharmacol 2019; 15 : 343-350.

Trop J Pharm Res, October 2019; 18(10):2226 
46. Zimmermann HW, Trautwein C, Tacke F. Functional role of monocytes and macrophages for the inflammatory response in acute liver injury. Front Physiol 2012; 3: 56.

47. Hu W, Wu L, Qiang Q, Ji L, Wang X, Luo H, Wu H, Jiang $Y$, Wang $G$, Shen $T$. The dichloromethane fraction from Mahonia bealei (Fort.) Carr. leaves exerts an antiinflammatory effect both in vitro and in vivo. $J$ Ethnopharmacol 2016; 188: 134-143.

48. Gulati K, Joshi JC, Ray A. Recent advances in stress research: focus on nitric oxide. Eur J Pharmacol 2015; 765: 406-414.
49. Ma $C H$, Liu JP, Qu R, Ma SP. Tectorigenin inhibits the inflammation of LPS-induced acute lung injury in mice. Chin J Nat Med 2014; 12: 841-846.

50. Cao Y, Li F, Luo Y, Zhang L, Lu S, Xing R, Yan B, Zhang H, Hu W. 20-hydroxy-3-oxolupan-28-oic acid attenuates inflammatory responses by regulating PI3K-Akt and MAPKs signaling pathways in LPS-stimulated RAW264.7 macrophages. Molecules 2019; 24: 386. 